\title{
Misi Yesus Ke Samaria: Analisis Yohanes 4:31-38
}

\author{
Yusuf L. M. \\ Sekolah Tinggi Teologi Injili Setia Siau \\ yusuflm1985@gmail.com
}

\begin{abstract}
The conversation between Jesus and the Samaritan woman was one that provoked a reaction from the disciples. After the conversation, the disciples immediately responded to the attitude of Jesus serving the Samaritan woman. However, it must be understood that this conversation was the starting point for the emergence of mass conversions in Samaria. The simple approach adopted by Jesus has brought about a sincere conversion of ethnic Samaritans who are often considered pagan by Conservative Jews.
\end{abstract}

Keywords: Missiology, John, Biblical Analysis

Abstrak: Percakapan Yesus dengan perempuan Samaria merupakan salah satu dialog yang menimbulkan reaksi para murid. Pasca percakapan tersebut langsung menimbulkan responss cepat para murid atas sikap Yesus yang melayani perempuan Samaria. Namun perlu dipahami bahwa justru percakapan tersebut menjadi titik awal munculnya pertobatan massal di Samaria. Pendekatan sederhana yang dipakai oleh Yesus telah membawa pertobatan yang sungguhsungguh dari etnis Samaria yang sering dianggap kafir oleh orang Yahudi Konservatif.

Kata Kunci: Misiologi, Yohanes, Analisis Biblika

\section{Pendahuluan}

Konteks Yohanes 4:31-38 masih merupakan bagian perikop tentang peristiwa percakapan Yesus dengan perempuan Samaria. Namun konteks ini tidak lagi menjelaskan tentang peristiwa tersebut, tetapi sudah masuk di dalam adegan peristiwa di mana Yesus tidak lagi berbicara dengan perempuan Samaria (ay. 28), tetapi berbicara kepada murid-murid-Nya. Jika diperhatikan dengan teliti, konteks ayat 31-38 adalah satu adegan peristiwa di mana terjadi percakapan pendek antara Yesus dengan para murid dan pokok pembicaraan mereka sangat sejajar dengan inti percakapan Yesus dengan perempuan Samaria. Van Houwelingen menjelaskan, bahwa "kemudian Yesus menjalin percakapan pendek dengan para murid yang kira-kira sejajar dengan percakapan dengan wanita Samaria itu. Kalau yang dibicarakan tadi ialah air yang hidup, kini pokok pembicaraannya ialah makanan yang khusus". ${ }^{1}$

Konteks pasal 4:1-42 terdiri dari dua fakta historis yakni percakapan Yesus dengan perempuan Samaria dan percakapan singkat Yesus dengan murid-murid-Nya, namun kedua peristiwa itu mempunyai makna yang sangat sejajar, karena pokok pembicaraan Yesus terhadap perempuan Samaria adalah air yang mempunyai arti khusus dan pokok pembicaraan Yesus Kepada murid-murid-Nya yakni makanan yang juga mempunyai arti khusus. Selain itu, pembahasan pada perikop ini juga sangat dekat dengan konteks percakapan Yesus dengan Nikodemus (3:1-21), konteks pasal 3:22-36. Hal ini tampak dari sistem penafsiran konteks 4:37-38 mengenai penggunaan kata a;lloj atau a;lloi yang artinya 'yang lain'. Penggunaan kata tersebut mengacu kepada bentuk pertanyaan tentang siapa penabur yang lain itu. Dengan demikian dapat dipahami bahwa perikop ini mengikuti pola susunan percakapan yang biasa dipakai oleh Injil Yohanes, karena

${ }^{1}$ P. H. R. van Houwelingen, Johannes Het Evangelie van het Woord (Yohanes: Injil Firman) (Kampen: Kok, 1997), 11. 
ketika Yesus mengatakan sesuatu yang mempunyai makna rohani pada awalnya selalu dipahami secara harafiah. ${ }^{2}$ Hal itu nampak dari percakapan Yesus dengan Nikodemus (3:1-21), perempuan Samaria (4:1-30) serta sangat jelas dalam pembahasan konteks pasal 4:31-38.

\section{Terjemahan (harfiah)}

Upaya untuk memahami dengan baik konteks Yohanes 4:31-38, maka perlu diberikan terjemahan harfiah sebagai bahan perbandingan dalam analisis selanjutnya:

Ay. 31. Pada sementara (itu) murid-murid meminta Dia, mereka berkata, Rabbi, makanlah.

Ay. 32. Tetapi Dia telah berkata kepada mereka, Aku mempunyai makanan yang tidak kamu tahu.

Ay. 33 Karena itu, murid-murid saling berkata kepada yang lain, tidakkah seseorang membawa makanan kepada Dia (untuk) dimakan?

Ay. 34 Yesus berkata kepada mereka, makanan-Ku adalah supaya melakukan kehendak yang mengutus Aku dan menyelesaikan pekerjaan-Nya.

Ay. 35 bukan(kah) kamu berkata bahwa, empat bulan lamanya lagi adalah bahwa datang musim menuai? Aku berkata kepadamu lihatlah, angkatlah matamu dan lihatlah ladang-ladang karena telah putih agar supaya dituai.

Ay. 36 yang menuai, dia menerima upah dan dia mengumpulkan buah untuk hidup yang kekal, sehingga penabur dan penuai sama-sama bersukacita/berbahagia.

Ay. 37 karena dalam hal ini, perkataan yang adalah benar bahwa, yang lain adalah menabur dan yang lain menuai.

Ay. 38 Aku mengutus kamu menuai yang tidak kalian kerjakan; mereka yang lain bekerja dan kamu datang ke dalam usaha mereka.

\section{Metode Penelitian}

Pada penelitian ini, penulis atau peneliti menggunakan pendekatan atau metode kualitatif untuk memperoleh data yang valid guna membangun sebuah teori yang berkaitan dengan tema atau pokok penelitian. Metode kualitatif yang dimaksud adalah mengkaji dan mengelaborasi setiap sumber, informasi dan data-data yang diperoleh dari pustaka.

\section{Hasil dan Pembahasan}

\section{Analisis Dialog Yesus dengan Para Murid di Wilayah Samaria}

\section{Ayat 31 "Permintaan para Murid supaya Yesus Makan"}

Pada peristiwa pertama yakni percakapan Yesus dengan perempuan Samaria sangat jelas terlihat bahwa pada ayat 27 ketika para murid datang kepada Yesus, maka percakapan dengan perempuan Samaria berhenti karena perempuan itu langsung pergi ke kota (ay. 28). Ayat 31 memperlihatkan suatu adegan baru yakni terjadi percakapan singkat antara Yesus dengan murid-murid-Nya. Pembicaraan kedua tersebut mempunyai makna sejajar dengan inti pembicaraan pertama.

Pokok penting yang perlu diperhatikan dalam teks ayat 31 kata metaxu. Kata ini mempunyai dua jenis penggunaan yakni digunakan sebagai kata depan dalam bentuk

${ }^{2}$ William Barclay, Pemahaman Alkitab Setiap Hari: Injil Yohanes 1-7 (Jakarta: BPK Gunung Mulia, 2011), 279. 
genetif yang berarti 'di antara' dan juga digunakan sebagai kata keterangan yang berarti 'sementara.' Di dalam teks ini, kata metaxu digunakan sebagai kata keterangan, sehingga phrase ' $\mathrm{E} \nu \tau \hat{\jmath} \mu \epsilon \tau \alpha \xi \mathrm{v}$ menunjuk kepada peristiwa yang terjadi sebelum orangorang dari kota Samaria datang kepada Yesus. ${ }^{3}$ Penggunaan kata metaxu menunjuk kepada keterangan situasi di mana peristiwa pembicaraan Yesus dengan para murid terjadi sebelum orang-orang dari kota Samaria datang untuk melihat Yesus karena perempuan Samaria itu sudah menyampaikan berita keselamatan kepada mereka. Selain itu, kata metaxu juga menunjuk kepada keterangan situasi di mana para murid sangat heran terhadap Yesus karena Dia sama sekali tidak memperhatikan makanan yang dibawah oleh mereka. ${ }^{4}$ Jadi, dapat disimpulkan bahwa phrase pertama ini mempunyai dua penekanan yakni pertama: mengenai situasi yang terjadi sebelum orang-orang Samaria datang kepada Yesus, kedua: mengenai situasi di mana para murid heran terhadap Yesus karena tidak mengutamakan makanan yang dibawah muridmurid-Nya.

Dengan munculnya dua penekanan situasi ini, maka diberi juga penekanan penting kepada kata kerja ๆ $\rho \omega ́ \tau \omega \nu$ (orang ketiga, jamak, indikatif imperfek aktif, dari kata '€ $\omega \tau \alpha \dot{\alpha} \omega)$, yang mempunyai arti harfiah 'bertanya' dan 'meminta'. ${ }^{5}$ Kata ini dapat dipahami bahwa para murid meminta atau mengundang Yesus untuk makan. Hal ini dilakukan oleh para murid karena memiliki anggapan bahwa hal itu sangat wajar dilakukan karena itulah tujuan, mereka masuk ke desa untuk membeli makanan dan mereka meninggalkan Yesus dalam keadaan lelah dan pasti Dia sudah lapar, sehingga ketika sudah datang membawa makanan maka mareka mempersilahkan Yesus untuk segera makan. ${ }^{6}$

Tindakan para murid meminta atau mempersilahkan Yesus untuk segera makan merupakan tindakan yang sangat wajar karena Yesus sudah melakukan perjalanan, sehingga dalam situasi ini jelas Yesus pasti lapar dan haus. Hal yang sama ditekankan oleh Van Houwelingen dengan menyatakan, bahwa "mereka tahu bahwa Dia sudah sangat haus dan lapar". ${ }^{7}$ Penekanan ini memberikan penegasan bahwa tindakan para murid meminta supaya Yesus makan sangat wajar dan patut dilakukan. Selain itu, kata

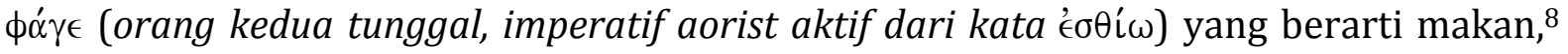
juga dapat dipahami bahwa para murid melihat Yesus pasti sudah haus dan lapar, oleh sebab itu mereka mempersilakan Dia untuk makan sedikit. ${ }^{9}$ Penekanan dalam bentuk imperatif tersebut, menunjukkan bahwa ada desakan dari para murid supaya Yesus mempergunakan waktu yang singkat itu untuk makan, sebelum orang-orang Samaria datang kepada Yesus sebagai respons atas berita yang dibawa perempuan Samaria.

\footnotetext{
${ }^{3}$ Fritz Rienecker, A Linguistik Key to the Greek New Testament (1980, Zondervan Publishing House, Grand Rapids, Michigan), 227.

${ }^{4}$ van Houwelingen, Johannes Het Evangelie van het Woord, 11.

${ }^{5}$ Rienecker, A Linguistik Key to the Greek New Testament, 227.

${ }^{6}$ Leon Morris, The Gospel according to John. Revised Edition (William B. Eerdman Publishing Company, Grand Rapids, Michigan, 1995), 244-45.

${ }^{7}$ van Houwelingen, Johannes Het Evangelie van het Woord, 11.

${ }^{8}$ Rienecker, A Linguistik Key to the Greek New Testament, 227.

${ }^{9}$ van Houwelingen, Johannes Het Evangelie van het Woord, 11. Dari tindakan para murid mempersilakan Yesus untuk makan merupakan suatu tindakan yang tulus mempedulikan kebutuhan Yesus secara fisik, sehingga di dalam kata 'Ev $\tau \hat{\omega} \mu \epsilon \tau \alpha \xi v$ (ada jarak waktu mendesak Yesus untuk makan) yakni dari perginya perempuan Samaria sampai kedatangan orang-orang Samaria, oleh karena itu para murid mendesak Dia dengan mengatakan "Guru makanlah", dan para murid melihat bahwa sudah waktunya makan dan pasti Yesus sudah lapar. Lih. William Hendriksen, New Testament Commentary: Exposition of the Gospel According to John, 172.
} 


\section{Ayat 32 "Yesus Mengalihkan Perhatian Para Murid kepada Tujuan Misi"}

Munculnya desakan dari para murid di dalam ayat 31 yakni supaya Yesus makan, maka Yesus memberi respons terhadap desakan tersebut. Yesus memberi respons terhadap makanan yang diberikan para murid dengan mengalihkan pembicaraan kepada hal-hal rohani dengan menjawab "pada-Ku ada makanan yang tidak kamu kenal". Jawaban Yesus ini mempunyai dua kata ganti yaitu "Aku dan kamu", kedua kata ini mempunyai penekanan dan menarik perhatian atas perbedaan besar antara Yesus dengan murid-murid-Nya. ${ }^{10}$

Kedua penekanan kata ganti yang digunakan oleh Yesus tersebut mempunyai arti yang sangat berlawanan. Hal ini menarik perhatian Leon Morris dengan menyatakan bahwa "jawaban Yesus meletakkan suatu jarak di antara mereka karena kata "Aku" dan "kamu" menekankan bentuk yang sangat kontras atau berlawanan".11 Dikatakan kontras karena para murid mempunyai pengertian yang lain terhadap tindakan mereka sedangkan Yesus juga menekankan pengertian yang sangat berbeda dan benar-benar tidak dipahami oleh murid-murid-Nya. Inti dari sifat kontras tersebut terjadi karena kata "makanan" yang digunakan di dalam phrase itu secara umum hanya menunjuk kepada sesuatu yang dapat dimakan, tetapi Yesus menjawab murid-murid-Nya dengan sesuatu yang tidak dipahami oleh mereka. ${ }^{12}$ Hal itu sangat jelas dari kata yang digunakan di dalam teks yakni kata brw/sin dalam bentuk akusatif tunggal feminim dari

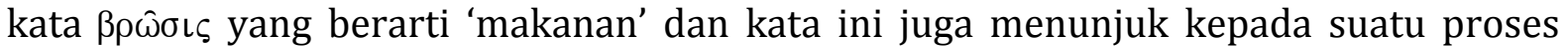
makan secara benar, namun di dalam teks ini kata itu sangat sinonim dengan kata 'makanan'.13 Respons Yesus dipahami oleh para murid dalam bentuk arti 'makanan' secara umum sehingga para murid berpikir di dalam ayat 33 bahwa Yesus sudah makan sesuatu, sehingga Dia tidak mempedulikan makanan yang dibawah oleh mereka. ${ }^{14}$

Dalam konteks ini memang Yohanes menggunakan dua bentuk terjemahan kata

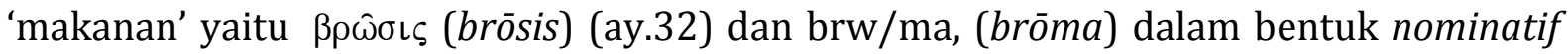
tunggal neuter yang juga berarti 'makanan' (ay.34). Yohanes menggunakan kedua kata ini dengan sedikit ada perbedaan penekanan yakni kata pertama itu menunjuk kepada tindakan 'makan' dalam arti secara umum, kedua menunjuk kepada 'sesuatu yang dimakan'.15 Dari kedua kata ini, Yohanes menggunakan kata pertama dalam memberikan respons kepada para murid, sehingga murid-murid-Nya memberikan respons bahwa Yesus sudah makan sesuatu dan mungkin ada orang yang memberikan Dia makan. Para murid sangat jelas tidak mengerti maksud Yesus di dalam respons tersebut. Maksud Yesus bukan menunjuk kepada kebutuhan secara fisik sedangkan pola pikir para murid mengarah kepada kebutuhan fisik atau jasmani. Dalam hal ini tidak berarti bahwa Yesus benar-benar tidak membutuhkan makanan secara jasmani, namun

\footnotetext{
${ }^{10}$ Tim Penerjemah, Tafsiran Alkitab Masa Kini 3: Matius-Wahyu (Jakarta: YKBK, 2012), 280

${ }^{11}$ Morris, The Gospel according to John, 245.

${ }^{12}$ Morris, The Gospel according to John, 245.

${ }^{13}$ Rienecker, A Linguistik Key to the Greek New Testament, 227.
}

${ }^{14}$ William Barclay memberikan penekanan lain mengenai mengapa Yesus tidak mempedulikan makanan yang dibawah oleh para murid dengan menyatakan bahwa pada waktu itu para murid telah kembali dari membeli makanan di kota dan mereka menawarkan makanan kepada Yesus, namun mereka telah meninggalkan Yesus di tepi sumur itu dalam keadaan lelah dan lemah sehingga mereka takut kalau Yesus tidak menginginkan lagi makanan yang baru mereka beli karena Dia sudah sangat lelah dan lemah. Tetapi di sisi lain Barclay juga setuju dengan menyatakan bahwa di dalam kesederhanan mereka, para murid menduga bahwa mungkin telah ada orang yang memberi-Nya makan. Lih. William Barclay, Pemahaman Alkitab Setiap Hari: Injil Yohanes 1-7 (Jakarta: BPK Gunung Mulia, 2011), 279-80.

${ }^{15}$ William Hendriksen, New Testament Commentary: Exposition of the Gospel According to John (Baker Academic, Grand Rapids, Michigan, 2007), 172. 
Yesus lebih mengutamakan tujuan misi-Nya. Andreas J. Köstenberger menyatakan, bahwa "di dalam respons Yesus dinyatakan dengan jelas bahwa memenuhi misi-Nya itu lebih penting dari pada makanan secara fisik atau jasmani"16 Yesus lebih mengutamakan untuk menjalankan misi-Nya dari pada memenuhi kebutuhan fisik yang secara jelas menjadi pokok pemikiran utama dari para murid. Hal ini semakin dipertegas oleh Carson dengan menjelaskan bahwa "mungkin juga Yesus benar-benar dalam keadaan haus (ay.7) dan lapar karena di tempat itu Yesus telah banyak bercakapcakap dengan perempuan Samaria tetapi Dia memutuskan untuk menggunakan kesempatan itu untuk mengajar para murid-Nya tentang sesuatu yang menjadi prioritasnya: pada-Ku ada makanan yang tidak kamu kenal". ${ }^{17}$ Jadi dapat disimpulkan bahwa sebenarnya Yesus sedang mengajarkan dan memberikan hal-hal yang bersifat prioritas kepada murid-Nya yaitu tujuan misi-Nya di dalam dunia ini.

\section{Ayat 33 “Maksud Yesus paradoks dengan maksud para murid mengenai makanan”}

Konteks ini secara jelas memperlihatkan respons dari para murid yang tidak memahami dan mengerti maksud makanan yang dimiliki oleh Yesus, sehingga mereka saling bertanya untuk mendapatkan informasi mengenai seseorang yang membawa makanan kepada Yesus. Di dalam teks ini menggunakan kata negasi $\mu$ '́ $(m \bar{e})$ yang diterjemahkan 'tidak' atau bukan' dan juga bisa diterjemahkan 'jangan-jangan', dan kata ini hanya digunakan di dalam pertanyaan yang tidak memerlukan jawaban. ${ }^{18}$ Maksud bentuk pertanyaan yang digunakan oleh para murid di dalam teks ini merupakan pertanyaan yang tidak memerlukan jawaban sebab mereka hanya bertanya di kalangan mereka sendiri yakni para murid yang secara jelas mereka tidak mengerti maksud perkataan Yesus. Kemudian kata tersebut dilanjutkan dengan kata $\eta^{\prime} \nu \in \gamma \kappa \in \nu$ merupakan kata kerja dalam bentuk orang ketiga tunggal indikatif aorist aktif dari kata ф'́ $\rho \omega$ yang diterjemahkan 'membawa' atau 'membawa kepada'.19 Mereka tidak mengerti maksud Yesus, maka mereka berpikir bahwa kemungkinan atau jangan-jangan (dari kata $\mu \eta$, ' $m \bar{e}$ ') ada orang yang membawa makanan kepada Yesus, sehingga Dia tidak membutuhkan makanan yang dibawah oleh mereka. Dalam hal ini, murid-murid tidak mengerti maksud Yesus dan perkataan-Nya dipahami secara literal dalam bentuk materi, sehingga pola pikir mereka hanya selalu mengarah kepada bentuk makanan secara jasmani. ${ }^{20}$ Jadi pemahaman para murid sangat paradoks dengan harapan Yesus terhadap mereka.

\footnotetext{
${ }^{16}$ Andreas J. Köstenberger, Baker Exegetical Commnetary on the New Testament: John (Baker Academic, Grand Rapids, Michigan, 2008), 161.

17 D. A. Carson, The Gospel According to John (Grand Rapids, Michigan: William B. Eerdmand Publishing Company, 1991), 228. Menurut Barclay, jalan yang paling cepat dari Yudea ke Galilea ternyata melalui daerah Samaria yang memerlukan waktu perjalanan selama tiga hari. Dan jalur lain yaitu menyeberang sungai Yordan dan arah timur lalu menyusuri daerah sebelah timur Yordan itu ke arah utara yang terletak di luar Samaria dan memerlukan waktu perjalanan enam hari, jadi Yesus sebenarnya menempuh jalur pendek ke Galilea maka Ia harus melewati daerah Samaria, sedangkan menurut Kruse, Yesus melewati daerah Samaria karena Dia mau menempuh jalur pendek yang sering dilewati oleh orang-orang dari Galilea menuju ke Yerusalem. Dan bagaimana pun di dalam narasi tersebut percakapan dengan perempuan Samaria yang membuat orang-orang banyak datang kepada-Nya. Jadi dalam hal ini menurut Kruse Yesus memang sangat membutuhkan untuk melalui Samaria karena Dia mempunyai tekat untuk pekerjaan Ilahi dan juga bisa karena faktor geografis. Lih. Barclay, Injil Yohanes 1-7, 249; bdk. Colin G. Kruse, John, 126.

${ }^{18}$ Rienecker, A Linguistik Key to the Greek New Testament, 227.

${ }^{19}$ Rienecker, A Linguistik Key to the Greek New Testament, 227.

${ }^{20}$ Morris, The Gospel according to John, 245.
} 
Tindakan para murid mengacu kepada cara berpikir untuk memenuhi kebutuhan jasmani. Yesus tidak mempunyai makanan ketika mereka pergi, sehingga mereka berpikir bahwa ada seseorang yang telah membawa sesuatu kepada Yesus dan jelas pikiran para murid mengarah kepada bahwa kemungkinan perempuan Samaria itu yang telah memberikan makanan kepada Yesus. Anggapan ini semakin jelas ketika muncul perkataan para Murid "adakah orang yang telah membawa sesuatu kepada-Nya untuk dimakan? dan pikiran para murid hanya mengarah kepada perempuan Samaria atau seseorang dari desa Samaria. ${ }^{21}$ Anggapan para murid bahwa sangat mungkin perempuan Samaria yang telah membawa sesuatu kepada Yesus. Sebab para murid tidak ada ketika terjadi percakapan antara Yesus dan perempuan Samaria itu, sehingga mereka tidak memahami dan mengerti makanan yang dimaksudkan oleh Yesus yakni makanan mengarah kepada Tuhan atau makanan rohani. ${ }^{22}$ Faktor ketidakhadiran mereka pada waktu Yesus berbicara dengan perempuan Samaria yang juga membuat mereka berpikir bahwa kemungkinan perempuan tersebut yang telah membawa makanan kepada Yesus.

\section{Ayat 34 "Penekanan misi utama Yesus melalui kata 'makanan-Ku'”}

Pada bagian ini, Yesus berbicara tentang sifat hakiki misinya yang berupa tindakan ketaatan melakukan dan menyelesaikan pekerjaan Bapa yang mengutus Dia. ${ }^{23} \mathrm{Hal}$ ini menunjukkan bahwa Yesus memperlihatkan kepada murid-Nya mengenai tujuan utama Dia datang ke dalam dunia. Hal itu diungkapkan oleh Yesus dengan kata $\beta \rho \omega \mu \alpha$, dalam bentuk nominative tunggal neuter, yang diterjemahkan 'makanan' ${ }^{24}$ Penggunaan kata ini memberikan penekanan tentang makanan yang tidak dimengerti oleh para murid. Prinsip dari kata tersebut adalah melakukan kehendak Allah harus mendahului kebutuhan jasmani, meskipun Yesus dalam konteks ini tidak menganjurkan untuk mengabaikan kebutuhan jasmani. ${ }^{25}$ Yesus menekankan prinsip yang benar kepada para murid supaya mereka mengutamakan kehendak Allah dan jangan hanya mengutamakan kebutuhan jasmani.

Phrase 'makanan-Ku' menjelaskan bahwa pekerjaan yang dilakukan oleh Yesus memberikan suatu kepuasan atau kesenangan di dalam jiwa-Nya. ${ }^{26} \mathrm{Hal}$ inilah yang menjadi dasar dan prinsip Yesus dalam menjalankan misi-Nya, sehingga para murid pun tidak mengerti maksud Yesus. Kemudian hal penting yang perlu ditekankan dalam teks ini adalah kata i $\nu \alpha$ (hina) yang merupakan kata penghubung dan mempunyai arti 'agar, supaya, sehingga', tidak hanya menekankan aspek tujuan tetapi juga menekankan kata benda yang digunakan sebagai subyek atau sebagai nominatif predikat. ${ }^{27}$ Dengan menggunakan kata ini, Yesus sangat menekankan diri-Nya sebagai subyek yang melakukan kehendak Bapa-Nya dengan menekankan sifat hakiki dari misi tersebut yakni ketaatan.

Penekanan sebagai subyek di dalam misi yang dilakukan oleh Yesus, hal itu sangat jelas di dalam penggunaan kata pe,myanto,j, kata kerja genetif tunggal maskulin partisip aorist aktif yang berasal dari kata pe,mpw artinya 'mengutus'. Dari kata ini, Houwelingen menegaskan bahwa "Yesus menyadari bahwa Dia diutus ke dunia untuk

21 Tim Penerjemah, Tafsiran Alkitab Masa Kini 3: Matius-Wahyu, 280-81; bdk. Hendriksen, New Testament Commentary, 172.

${ }^{22}$ Hendriksen, New Testament Commentary, 172.

${ }^{23}$ Bruce Milne, Yohanes (Jakarta: YKBK, 2010), 119.

${ }^{24}$ Rienecker, A Linguistik Key to the Greek New Testament, 227.

${ }^{25}$ Tim Penerjemah, Matius-Wahyu, 281.

${ }^{26}$ Hendriksen, New Testament Commentary, 172.

${ }^{27}$ Rienecker, A Linguistik Key to the Greek New Testament, 227. 
melakukan kehendak Allah (lih.5:36-38) di dalam pengutusan-Nya itu terkandung tugas hidup yang akbar, yang harus dipenuhi-Nya di masa depan". ${ }^{28}$ Ungkapan Yesus tentang kata kerja 'mengutus' sangat jelas memperlihatkan Yesus yang sungguh-sungguh menyadari akan tugas-Nya dan tugas tersebut akan diselesaikan. Kemudian dalam menyelasaikan tugas-Nya, Yesus menggunakan kata di teks ini adalah $\tau \in \lambda \in \iota \omega \sigma \omega \omega$ (orang pertama, tunggal, subj. aorist aktif, dari kata $\tau \in \lambda \in \operatorname{ló} \omega)$ yang menunjuk kepada 'menyelesaikan, menyempurnakan atau membawa dan menyelesaikan pekerjaan yang sudah dimulai dari Bapa, dan jika diteliti penggunaan kata ini, sebenarnya mempunyai kesamaan akar kata dari kata yang diucapkan oleh Yesus di dalam 19:28, 30 yakni tete,lestai artinya 'sudah selesai'. ${ }^{29}$ Jadi dapat dipahami bahwa Yesus yang membawa tugas misi di dalam dunia ini, dikerjakan oleh Yesus dengan sungguh-sungguh dan Dia merasakan suatu kepuasan atau menikmati akan tugas tersebut.

Houwelingen menjelaskan, bahwa "sebetulnya yang dilakukan oleh Yesus itu ialah pekerjaan Allah (bentuk tunggal: bnd. 17:4), dan untuk melakukan pekerjaan itulah maka Yesus bahkan tidak sempat makan, namun tugas-Nya yang khusus itu memberi nilai makanan yang paling tinggi bagi hidup-Nya dan sungguh-sungguh sangat memuaskan hati-Nya. ${ }^{30}$ Hal yang sama ditekankan oleh Kruse. Menurutnya "makanan yang Dia punya, yang mereka tidak ketahui itu adalah melakukan kehendak Bapa dan secara sempurna telah diberikan untuk dikerjakan dan itulah yang menjadi tujuan Yesus datang ke dalam dunia $(6: 38 ; 9: 4 ; 17: 4)$. Jadi dengan mengatakan hal itu merupakan sesuatu yang paling menyenangkan bagi-Nya, sehingga Dia mengatakan "makanan-Ku dan minuman-Ku" adalah melakukan kehendak Bapa dan sempurna di dalam pekerjaan-Nya". ${ }^{31}$ Dengan demikian dapat dipahami bahwa perkataan Yesus di dalam teks ini sangat menekankan tentang Yesus yang benar-benar mempunyai ketaatan dalam menjalankan tugas-Nya dan tugas itu dipandang sebagai kebutuhan pokok yang mempunyai nilai yang sangat tinggi, sehingga sangat wajar kalau Dia tidak mempedulikan makanan yang dibawa oleh para murid. ${ }^{32}$

\section{Ayat 35 “Musim menuai tiba"}

Teks ini diawali dengan perkataan murid-murid Tuhan Yesus. Perkataan tersebut kembali diucapkan oleh Yesus dalam bentuk pertanyaan 'bukankah kamu mengatakan: Empat bulan lagi tibalah musim menuai? Bentuk pertanyaan ini tidak perlu dijawab karena inti dari pertanyaan tersebut merupakan salah satu bagian pembicaraan mereka di dalam perjalanan. Houwelingen menjelaskan, bahwa "Empat bulan lagi musim menuai $t i b a,{ }^{33}$ itulah yang dikatakan oleh para murid Yesus dalam perjalanan mereka ketika melewati ladang-ladang di sekitar daerah itu."34 Pertanyaan itu sudah pasti dipahami

\footnotetext{
${ }^{28}$ van Houwelingen, Johannes Het Evangelie van het Woord, 11.

${ }^{29}$ Rienecker, A Linguistik Key to the Greek New Testament, 227; bdk. Hendriksen, New Testament Commentary, 172.

${ }^{30}$ van Houwelingen, Johannes Het Evangelie van het Woord, 11.

${ }^{31}$ Kruse, John, 138-39.

${ }^{32}$ Milne menegaskan mengenai kepuasan ini dengan menyatakan bahwa ketika Yesus berbicara tentang kepuasan melakukan misi-Nya, hal itu ibarat makanan yang memuaskan dan menguatkan. Milne, Yohanes, 119.

${ }^{33}$ Menurut Barclay, orang Yahudi membagi tahun dalam enam masa, menurut masa yang dihubungkan dengan kegiatan pertanian. Tiap masa berlangsung selama dua bulan, dan masa-masa itu ialah masa pembenihan, masa dingin, masa semi, masa panen, masa panas dan masa terik. Yesus mengatakan: "kamu mempunyai peribahasa: kalau menyamaikan benih, maka engkau harus menunggu paling sedikit empat bulan untuk dapat berharap akan bisa mulai menuai." Jadi maksud Barclay dalam konteks ini, hanya merupakan suatu interval waktu antara masa menabur dan masa menuai.

${ }^{34}$ van Houwelingen, Johannes Het Evangelie van het Woord, 11.
} 
para murid karena hal itu merupakan bagian dari bahan percakapan mereka dalam perjalanan. Kata penting dalam phrase tersebut yang perlu ditekankan adalah kata tetra,mhno,j yang merupakan kata sifat nominatif, tunggal, maskulin, dari kata tetra,mhno,j, artinya: empat bulan. Sebagai subyek dalam kalimat tanya tersebut tentu memberikan penjelasan mengenai kapan musim menuai itu berlangsung dan apakah mungkin pada waktu itu sudah berlangsung musim menuai di Samaria? Barclay menjelaskan pokok ini. Menurutnya, tidak harus menduga bahwa Yesus berbicara tentang musim yang pada waktu itu terjadi di Samaria, kalau memang hal itu yang dimaksudkan-Nya maka peristiwa itu tentu terjadi di sekitar bulan januari, karena pada waktu itu tidak akan ada terik matahari yang sangat melelahkan, dan juga air tidaklah sulit dicari, orang tidak perlu mengambil air ke sumur, sebab pada bulan januari masih berlangsung musim hujan dan air bisa dengan muda diperoleh di mana-mana.

Pernyataan di atas memberi penegasan bahwa ketika Yesus berbicara mengenai frasa "Empat bulan lagi musim menuai tiba" maka tidak bisa diambil kesimpulan bahwa pada saat itu adalah musim menuai di Samaria, karena kalau hal itu terjadi, maka kemungkinan peristiwa itu terjadi sekitar bulan januari. Hal yang sama ditekankan oleh Carson bahwa "dari penyebutan "empat bulan" telah diperkirakan waktu peristiwa sekitar Desember atau Januari, empat bulan sebelum muncul secara normal musim menuai atau panen". ${ }^{5}$ Kedua pernyataan di atas dapat disimpulkan bahwa penyebutan frasa 'empat bulan' menunjuk kepada peristiwa musim panen yang akan terjadi sekitar bulan Desember atau awal Januari, namun di Samaria waktu itu belum tiba musim menuai. Pada saat itu di Samaria masih berlangsung musim dingin, dan tanaman di ladang baru akan matang empat bulan kemudian yakni kalau musim semi tiba. ${ }^{36}$

Selanjutnya, kata yang menjadi penekanan penting dalam kalimat itu adalah ó

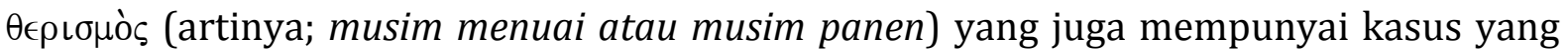

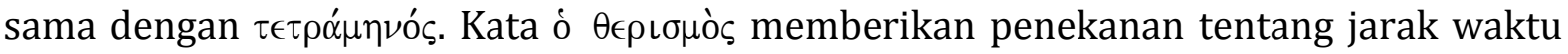
antara akhir musim menabur dengan awal musim menuai yang berlangsung selama empat bulan. ${ }^{37}$ Craig S. Keener menekankan hal tersebut bahwa "banyak yang berpikir bahwa frasa "empat bulan, kemudian menuai" adalah hanya sebuah pepatah yang tidak dikenal, namun arti dari frasa tersebut menunjuk kepada waktu sekarang di mana para pekerja dengan giat menabur dan nanti empat bulan kemudian mereka akan menuai."38 Secara keseluruhan dari frasa tersebut lebih berfokus kepada penekanan tentang interval waktu antara musim menabur dan musim menuai.

Setelah Yesus berbicara tentang interval waktu, kemudian Dia mengarahkan perhatian para murid pada ladang-ladang di sekitar Sikhar yang masih berada dalam musim dingin. ${ }^{39}$ Teks ini menekankan ungkapan Yesus tentang "lihatlah di sekelilingmu dan pandanglah ladang-ladang yang sudah menguning dan matang untuk dituai".

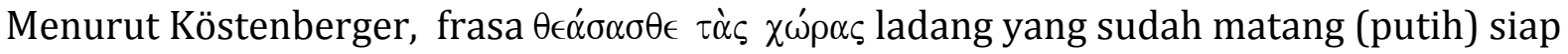
untuk dituai, dan jika ungkapan sebelumnya diterjemahkan secara literal, maka 'ladang' yang dimaksudkan tidak secara nyata matang untuk dituai, tetapi sepertinya perkataan Yesus ini merupakan metafora yang secara literal karena Yesus dan murid-murid-Nya sudah mendekati kumpulan orang-orang Samaria yang memakai jubah putih. ${ }^{40}$ Ketika

\footnotetext{
${ }^{35}$ Carson, The Gospel According to John, 229.

${ }^{36}$ van Houwelingen, Johannes Het Evangelie van het Woord, 11.

${ }^{37}$ Rienecker, A Linguistik Key to the Greek New Testament, 227.

${ }^{38}$ Craig S.Keener, The Gospel of John A Commentary. Vol. 1 (Peabody, Massachusetts: Hendrikson Publishers, 2005), 625.

${ }^{39}$ van Houwelingen, Johannes Het Evangelie van het Woord, 11.

${ }^{40}$ Köstenberger, John, 162.
} 
Yesus berbicara tentang 'ladang yang sudah matang', hal itu dapat dipahami secara metafora atau hanya sebagai gambaran mengenai panen jiwa-jiwa, namun hal ini juga dapat dipahami secara literal karena pada waktu Yesus menggunakan metafora tersebut, sebenarnya Yesus dan murid-muridnya sudah melihat kumpulan orang-orang Samaria yang memakai jubah putih. Sebenarnya pandangan Yesus tidak mengarah kepada berkas-berkas gandum karena belum saatnya musim menuai (gandum belum matang), tetapi lebih mengarah kepada orang-orang Samaria. Pendapat Ramsey Michaels perlu disimak: Yesus mengumumkan dengan tegas (Aku berkata kepadamu, lihatlah!) bahwa waktu menunggu sudah lewat; "lihatlah dengan matamu dan pandanglah ladang-ladang itu yang sudah putih untuk dituai”, dan pada waktu itu orang-orang Samaria sementara berjalan menuju kepada mereka ketika Yesus sementara berbicara (ay.30), dan Yesus berbicara kepada murid-muridnya tentang 'panen/menuai', yang Dia maksudkan adalah panen jiwa-jiwa bukan panen berkasberkas gandum. ${ }^{41}$ Ini memberikan pemahaman bahwa Yesus menggunakan perkataan tersebut sebagai gambaran untuk menyelamatkan umat manusia khususnya di Samaria.

Dengan demikian dapat disimpulkan bahwa ada dua penekanan dari perkataan Yesus itu yakni pertama: secara jelas ketika Yesus berbicara memang sedang menunjuk kepada ladang-ladang di Sikhar yang pada waktu itu masih berlangsung musim dingin dan bukan musim menuai dalam arti gandum belum matang (putih) untuk dituai. Kedua: perkataan Yesus itu menjadi satu gambaran tentang panen jiwa-jiwa di Samaria, karena kata $\chi \omega$ ' $\alpha \varsigma$ dapat diterjemahkan 'daerah', dalam hal ini menunjuk kepada daerah di Samaria, di mana di daerah tersebut orang-orang Samaria sedang menuju kepada Yesus dan hal ini menunjukkan waktunya sudah tiba untuk menuai jiwa-jiwa.

\section{Ayat 36 "Penabur dan penuai sama-sama mendapat upah"}

Bagian penting yang perlu diberi penekanan di dalam teks ini adalah frasa

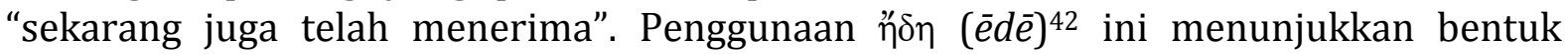
waktu bagi para penuai untuk menerima upahnya dan mengumpulkan buah. Kata $\eta \delta \eta$ (édē) menekankan metafora dari ladang-ladang yakni "putih untuk dituai" dan menjadi gambaran mengenai "penuai dan penabur" penggunaan istilah ini menjadi suatu bahan perumpamaan mengenai "panen/tuaian" yang dapat diartikan merupakan panen jiwa-

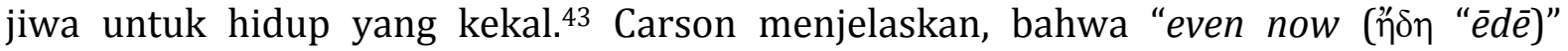
menunjuk kepada penuai yang sedang bekerja, tidak hanya menunggu sampai musim panen tiba, karena panen yang sesungguhnya sekarang telah datang, jadi penuai sibuk mengumpulkan buah untuk hidup yang kekal. Hasil panen itu menunjuk kepada orangorang yang mengikut Yesus, dan hal ini pertama-tama mengarah kepada orang-orang Samaria". ${ }^{4}$ Penuai dalam hal ini tidak perlu menunggu waktu yang lain untuk bekerja karena tuaian sudah siap dan hal ini nampak dari tindakan orang-orang Samaria yang datang kepada Yesus. Tetapi perlu dipahami bahwa penggunaan kata telah tersebut bukan menggambarkan pekerjaan tersebut sudah sempurna atau sudah selesai namun

\footnotetext{
${ }^{41}$ Michaels, The Gospel of John, 262.

${ }^{42}$ Dalam terjemahan NAS, “Already”, dan kata ini digunakan dalam bentuk kata keterangan 'telah' yakni sesuatu yang sudah terjadi. Jadi kata ini menekankan bahwa penabur dan penuai sudah menerima upah.

${ }^{43}$ Michaels, The Gospel of John, 264.

${ }^{44}$ Carson, The Gospel According to John, 230. Selain itu, Morris menjelaskan kata "even now" dengan menyatakan bahwa kata tersebut mengarah kepada kesiapan seseorang supaya bersemangat dan aktif dalam tuaiannya dan di dalam menerima upanya. Dan secara umum pemberian upah menjadikan pekerjaan itu semakin sempurna. Dan hal ini juga mengindikasikan suatu tugas yang sangat penting yang sedang dihadapi oleh para murid. Lih. Morris, The Gospel according to John, 247.
} 
terus berkelanjutan. Hal ini sangat jelas terlihat dari kedua kata kerja yang digunakan dalam teks ini yakni $\lambda \alpha \mu \beta \alpha ́ v \epsilon \iota$ dan $\sigma v \nu \alpha ́ \gamma \epsilon \iota$ yang sama-sama menggunakan tense present bukan tense aorist yang menunjukkan bahwa pekerjaan tersebut bukan berarti sudah lengkap dan sempurna sehingga tidak perlu lagi bekerja melainkan suatu pekerjaan yang terus berkelanjutan. ${ }^{45}$ Dari penekanan ini dapat disimpulkan bahwa kata éde dalam teks ini jelas memberi pemahaman tentang para penuai yang sedang mengerjakan tugas yang sangat penting dan langsung menerima upah dari pekerjaannya, karena dengan demikian akan membuat pekerjaan tersebut semakin lengkap dan sempurna.

Selanjutnya, frasa "penabur dan penuai sama-sama bersukacita" menjadi penekanan penting dan menarik untuk diteliti karena konteks ini memperlihatkan tentang 'penabur dan penuai' hadir secara bersamaan di dalam satu pekerjaan. Namun perlu dipahami bahwa, penabur dan penuai adalah dua status orang yang berbeda dalam dunia pertanian dan tidak pernah bekerja secara berdampingan, melainkan secara bergantian (bdk. Ul. 28:30; Ayb. 31:8; Mi. 6:15), jadi tidak mungkin dikatakan bahwa penabur dengan sendirinya melihat dari hasil pekerjaannya, tetapi di Samaria terjadi peristiwa yang sangat langkah di mana penabur dan penuai saling bertemu dan bersama-sama bersikacita (bnd. Im.26:5; Am. 9:13).46

Jadi, apa yang menjadi penekanan penting mengenai kehadiran 'penabur dan penuai' secara bersamaan? Menurut Ramsey, kata tersebut yakni $\alpha$ í $\rho ̣$ yang berarti 'bersukaria' atau bergirang' menunjuk kepada suatu tanda dalam menyelesaikan suatu penyerahan tugas dan menjadi sifat atau karakteristik keberhasilan dalam musim menuai. ${ }^{47}$ Tugas yang diberikan kepada penabur dan penuai merupakan suatu sukacita besar dan tindakan bersukacita dalam menjalankan pekerjaan tersebut pasti mencapai keberhasilan. Selain itu, phrase tersebut memberi dua penekanan yakni pertama: tentang panggilan terhadap janji yang bersifat eskatologi yang merujuk kepada nubuatan dalam Amos 9:13, di mana Yesus menggunakan nada eskatologis untuk memunculkan pelayanannya yakni penabur dan penuai datang secara bersama-sama di dalam musim menuai untuk mengumpulkan hasil panen, kedua, Yesus memberi kesempatan kepada para penabur yang lain untuk mempersiapkan diri dalam pekerjaan yang terdapat dalam teks 37 dan 38.48 Dengan demikian dapat dipahami bahwa kehadiran penabur dan penuai secara bersama-sama dalam musim menuai menjadi suatu pengharapan yang bersifat eskatologis. Pekerjaan penabur dan penuai akan menikmati secara bersama-sama hasil panen mereka. Selain itu, Yesus sedang mempersiapkan para penabur dan sekaligus penuai untuk menuai (ay.38).

\section{Ayat 37-3849 "Penabur dan penuai bekerja bersama dan menuai bersama"}

Pokok penting yang perlu ditekankan dalam teks ini penggunaan kata ó $\lambda o ́ \gamma o \varsigma$ (ho logos). $\lambda o ́$ ó memang tidak memberikan pokok pemikiran yang lebih spesifik tetapi memberikan suatu prinsip. Hal itu sangat jelas dalam teks kuno Yahudi dan Yunani, di mana di dunia ini tidak selamanya selalu adil yakni manusia tidak selamanya mendapat

\footnotetext{
${ }^{45}$ Michaels, The Gospel of John, 264.

${ }^{46}$ van Houwelingen, Johannes Het Evangelie van het Woord, 12.

${ }^{47}$ Michaels, The Gospel of John, 265.

${ }^{48}$ Carson, The Gospel According to John, 230.

49 Kedua pokok ini penulis gabung dalam satu bagian karena kedua teks tersebut menekankan hal yang sama untuk diberi perhatian khusus dalam penelitian yaitu "yang seorang menabur dan yang lain menuai atau yang satu menuai yang lain mengusahakan"
} 
sukacita dari buah pekerjaan mereka. ${ }^{50}$ Di dunia ini sering memunculkan suatu fakta yang bersifat paradoks. Tetapi dalam konteks ini, ho logos menekankan bahwa Yesus secara tegas memberikan suatu perkataan yang bersifat positif yaitu menunjuk kepada kata $\dot{\alpha} \lambda \eta \theta \iota \nu$ ò (alèthinos) yang artinya 'benar' dan kata ini menjadi dasar dari perkataan Yesus dalam menjelaskan mengenai perkataan yang 'benar' di dalam ayat 38 yaitu "Aku

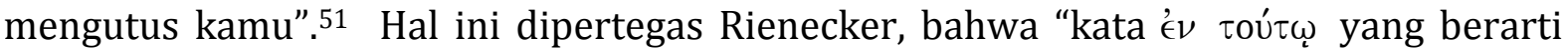
"dalam hal ini" bukan hanya menunjuk kepada ayat sebelumnya yakni 36 tetapi juga menunjuk kepada 38". ${ }^{52}$ Jadi, perkataan Yesus tersebut bukan bersifat paradoks tetapi bersifat positif yakni suatu perkataan yang benar dan berotoritas. Dari perkataan yang berotoritas tersebut semakin meneguhkan tugas misi dalam ayat 36 dan juga mempertegas pengutusan Yesus terhadap para murid serta tindakan pengutusan secara secara umum untuk pergi menuai. Penekanan ini muncul dari kata yang digunakan kata kerja yaitu $\dot{\alpha} \pi \epsilon ́ \sigma \tau \epsilon \iota \lambda \alpha \dot{u} \mu \hat{\alpha} \varsigma$, di mana kata ini memang menunjuk kepada pengutusan para murid tetapi juga pengutusan secara umum, sebab kata kerja $\dot{\alpha} \pi \epsilon \sigma \tau \epsilon \iota \lambda \alpha$ (orang pertama/tunggal/indikatif/aorist/aktif) memang dalam bentuk past tense (sent) tetapi bisa juga dipakai dalam bentuk tense present (send) sehingga ketika Yesus berbicara "Aku mengutus kamu", hal itu bukan hanya mengarah kepada para murid tetapi juga kepada tugas misi secara umum. ${ }^{53}$

Selain itu, pokok penting yang perlu dipahami dan dimengerti dengan baik teks ini adalah penggunaan kata $\alpha 2 \lambda$ oı (alloi) dalam bentuk nominatif jamak makskulin dari kata ¿ $\lambda \lambda$ o artinya "yang lain". Pemakaian kata tersebut menimbulkan berbagai penafsiran yang berbeda di antara para teolog, yaitu pertanyaan: siapa yang ditekankan dalam frasa 'yang lain?' Menurut Cramer dan Robinson, frasa tersebut

Menunjukkan bahwa sebelum ditangkap, Yohanes pembaptis dan para muridnya justru telah bekerja di tengah-tengah penduduk Samaria. Nabi pertobatan itu telah membaptis di Ainon dekat Salim di lembah Yordan yang sama tingginya dengan Samaria (lih. 3:22:24). Melalui khotbah dan baptisan Yohanes, yaitu nabi yang terakhir telah melakukan pekerjaan pendahuluan yang penting bagi Yesus. Dan meskipun sementara itu dia dilumpuhkan karena ditahan dalam penjara, pekerjaan persiapannya bagi kerajaan yang akan datang sama sekali tidak sia-sia. Yesus dan para pembantu-Nya mengikuti tapak kaki Yohanes dan para muridnya. Secara praktis mereka dapat saling berjabatan tangan: dia yang membaptis dalam air dan Dia yang akan membaptis dalam Roh Kudus. ${ }^{54}$

Pandangan di atas menegaskan bahwa frasa 'yang lain' menunjuk kepada Yohanes Pembaptis dan murid-muridnya yang sudah terlebih dahulu merintis pelayanan Yesus dan murid-murid-Nya di Samaria. Oleh kerena itu, Yohanes dan muridnya disebut sebagai penabur sedangkan Yesus dan para murid-murid-Nya disebut sebagai penuai. ${ }^{55}$

\footnotetext{
${ }^{50}$ Michaels, The Gospel of John, 265.

${ }^{51}$ Michaels, The Gospel of John, 265.

${ }^{52}$ Rienecker, A Linguistik Key to the Greek New Testament, 227.

${ }^{53}$ Köstenberger, John, 163.

${ }_{55}^{5}$ van Houwelingen, Johannes Het Evangelie van het Woord, 12.

${ }^{55}$ Beberapa pandangan lagi dari para teolog mengenai phrase 'yang lain' adalah Olsson dan Schneidewr berpendapat bahwa Allah adalah penabur dan Yesus adalah penuai dan selanjutnya sangat jelas menunjuk kepada peran par murid dalam memetik hasilnya. Menurut Lagrange dan Lindars berpendapat bahwa Yesus dan para murid didahului oleh para nabi yang telah menabur firman Allah. Hoskyns dan Witherington melihat Yesus dan wanita Samaria sebagai penabur dan para murid-Nya sebagai penuai, tetapi melupakan data bahwa
} 
Menurut Hendriksen, banyak orang memahami bahwa hal itu menunjuk kepada Musa, nabi-nabi PL, dan sangat dekat konteks di mana Allah di sini menunjuk kepada diri-Nya sendiri, juga mengarah kepada pekerja yang telah Ia bentuk di dekat sumur (4:26) dan perempuan Samaria yang telah lebih dulu bekerja $(4: 29,39)$, keduanya yakni Yesus dan perempuan Samaria yang telah bekerja di tengah-tengah orang Samaria, dan Yesus tidak secara langsung tetapi melalui perempuan Samaria. ${ }^{56}$ Hendriksen memahami ini bahwa penabur tersebut adalah Allah dan juga bisa menunjuk kepada Yesus dan perempuan Samaria. Selain itu, Kruse memberikan penekanan yang hampir sama dengan Hendriksen. Menurutnya, beberapa anggapan yang menegaskan bahwa frasa itu

Menunjuk kepada Yohanes pembaptis, tetapi ada anggapan lain yakni menunjuk kepada Bapa sebagai penabur dan Anak sebagai penuai. Hal ini konsisten dengan tema di dalam Injil yakni kerjasama Anak bekerja di dalam Bapa. Alternatif lain adalah menunjuk kepada pernyataan yang secara umum yang dapat diartikan kerja keras sebagai awal dari memproklamirkan kerajaan yang akan bersukacita dan proklamasi tersebut menuntun kepada komitmen akhir. Pernyataan secara umum itu didukung oleh fakta di dalam teks di mana Yesus mengutus murid-murid-Nya. ${ }^{57}$

Kruse, di satu sisi menekankan bahwa frasa itu menunjuk kepada Yohanes pembaptis dan Bapa, juga bisa menunjuk kepada suatu komitmen di dalam tugas dan akhirnya dapat bersukacita di dalam kerajaan. Carson menyimpulkan ke dalam dua penekanan yakni pertama, kesuksesan di dalam bekerja secara normal ditentukan oleh pekerja yang telah bekerja sebelumnya; kedua, hal itu menjadi contoh di mana penabur dan penuai bekerja bersama-sama, tetapi hal ini merupakan contoh berkat eskatologis yang akan datang. ${ }^{58}$ Dengan demikian, penabur yang lain itu bisa menunjuk kepada pekerja yang telah bekerja di Samaria sebelum Yesus, bisa menunjuk kepada Yesus sendiri, dan juga mengarah kepada berkat eskatologis.

\section{Kesimpulan}

Berdasarkan analisis teks di atas maka dapat disimpulkan beberapa sebagai berikut:

1. Konteks ini mengajarkan para murid-Nya tentang sesuatu yang menjadi prioritasnya. Hal itu Nampak di dalam jawaban Yesus "pada-Ku ada makanan yang tidak kamu kenal", sebenarnya Yesus sedang mengajarkan dan memberikan hal-hal yang bersifat prioritas kepada murid-Nya yaitu tujuan misiNya di dalam dunia ini.

2. Konteks ini menekankan sikap Yesus yang seolah-olah mengabaikan makanan yang dibawa murid-Nya bahwa sesuatu yang paling menyenangkan bagi-Nya

murid Yesus dalam periode ini belum bekerja secara mandiri. Wikenhauser dan Okure memikirkan periode sesudah paskah ketika para rasul boleh memetik hasil dari apa yang telah ditaburkan oleh Yesus atas perintah bapa-Nya. Brown dan Becker menunjuk kepada periode kerja yang lebih kemudian di Samaria, di mana penginjil Filipus bertindak sebagai penabur dan kedua rasul Petrus dan Yohanes sebagai penuai. Sedangkan Bultman dan Haenchen menyatakan bahwa naskah itu harus dibaca sebagai ucapan yang umum yakni setiap penginjil mengenang kembali pekerjaan seorang pendahulunya. Lih. van Houwelingen, Johannes Het Evangelie van het Woord, 12 .

${ }^{56}$ Hendriksen, Exposition of the Gospel According to John, 175.

${ }^{57}$ Kruse, John, 140. Kruse juga tidak memberikan kesimpulan yang pasti dalam hal ini karena dia juga menyatakan bahwa frasa 'yang lain' bisa menunjuk kepada Yohanes pembaptis dan murid-muridnya dan juga bisa menunjuk kepada Yesus sendiri.

${ }^{58}$ Carson, The Gospel According to John, 231. 
sehingga Dia mengatakan "makanan-Ku dan minuman-Ku" adalah melakukan kehendak Bapa dan sempurna dalam pekerjaan-Nya. Dalam hal ini Yesus benarbenar mempunyai ketaatan dalam menjalankan tugas-Nya dan hal itu dipandang sebagai kebutuhan pokok yang mempunyai nilai yang sangat tinggi.

3. Frasa "lihatlah dengan matamu dan pandanglah ladang-ladang itu yang sudah putih untuk dituai" memberi penekanan: pertama, secara jelas ketika Yesus berbicara memang sedang menunjuk kepada ladang-ladang di Sikhar yang pada waktu itu masih berlangsung musim dingin dan bukan musim menuai dalam arti gandum belum matang (putih) untuk dituai; kedua, perkataan Yesus itu menjadi satu gambaran tentang panen jiwa-jiwa di Samaria, karena kata cw,raj dapat diterjemahkan 'daerah', dalam hal ini menunjuk kepada daerah di Samaria, di mana di daerah tersebut orang-orang Samaria sedang menuju kepada Yesus dan hal ini menunjukkan waktunya sudah tiba untuk menuai jiwa-jiwa sebagai tujuan misi yang paling tinggi.

4. Istilah penabur dan penuai memberi pengajaran bahwa misi yang mengedepankan keselamatan jiwa-jiwa akan mendapat berkat pemeliharaan Tuhan saat ini maupun berkat yang bersifat eskatologis. Hal itu jelas dalam pekerjaan penabur dan penuai yang akan menikmati secara bersama-sama hasil panen mereka.

\section{Referensi}

Barclay, William. Pemahaman Alkitab Setiap Hari: Injil Yohanes 1-7. BPK Gunung Mulia, Jakarta, 2011.

Bruce Milne. YOHANES: Lihatlah Rajamu. Jakarta: YKBK, 2010.

Carson, D. A. The Gospel According to John. The Pilar New Testament. Grand Rapids, Michigsn: William B. Eerdmand Publishing Company, 1991.

Hendriksen, William, New Testament Commentary: Exposition of the Gospel According to John. Grand Rapids, Michigan: Baker Academic, 2007.

Van Houwelingen, P. H. R. Johannes Het Evangelie van het Woord. Kok: Kampen, 1997.

Keener, Craig S. The Gospel of John A Commentary. Vol. 1. Peabody, Massachusetts: Hendrikson Publishers, 2005.

Köstenberger, Andreas J. John. Baker Exegetical Commentary on the New Testament. Grand Rapids, Michigan: Baker Academic, 2008.

Kruse, Colin G. The Tyndale New Testament Commentaries: JOHN. Momentum, Surabaya, 2007.

Michaels, J. Ramsey. The New International Commentary on the New Testament: The Gospel of John. Grand Rapids: William B. Eerdmans Publishing Company, 2010.

Morris, Leon. The Gospel according to John. Grand Rapids: William B. Eerdman Publishing Company, 1995.

Rienecker, Fritz. A Linguistik Key to the Greek New Testament. Grand Rapids, Michigan: Zondervan Publishing House, 1980).

Tim Penerjemah. Tafsiran Alkitab Masa Kini 3: Matius-Wahyu. Jakarta: Yayasan Komunikasi Bina Kasih, 2012. 